\title{
Microstructure and Viscosity of Dephosphorization Slag in New Double Slag Converter Steelmaking Process
}

\author{
Wenkui YANG, Jian YANG, ${ }^{*}$ Runhao ZHANG and Han SUN \\ State Key Laboratory of Advanced Special Steel, School of Materials Science and Engineering, Shanghai University, Shanghai, \\ 200444 China.
}

(Received on April 11, 2021; accepted on June 11, 2021)

\begin{abstract}
The structure and viscosity of the dephosphorization slag in new double slag converter steelmaking process with low basicity slag at the low temperature range of $1573 \mathrm{~K}-1723 \mathrm{~K}$ are studied with hightemperature laboratorial experiments. With increasing the end temperature of dephosphorization, the viscosities of different slags decrease rapidly at first, then decrease slowly, and the slag activation energies increase. The values of Non-Bridging Oxygen per Silicon (NBO/Si) decrease, indicating the increase in the degree of polymerization (DOP) of the dephosphorization slag and the viscous flow activation energy of the dephosphorization slag. The results of Raman and FTIR spectroscopy are consistent. The dephosphorization slag in the temperature range of $1573 \mathrm{~K}-1673 \mathrm{~K}$ is mainly composed of the P-rich region, Fe-rich region and liquid region. With increasing temperature from $1573 \mathrm{~K}$ to $1673 \mathrm{~K}$, the proportion of the liquid region in slag increases, but the P-rich and Fe-rich regions correspondingly decrease.
\end{abstract}

KEY WORDS: dephosphorization; dephosphorization slag; viscosity; microstructure; Raman spectra; low temperature; low basicity.

\section{Introduction}

The new double slag converter steelmaking process (NDSP) mainly contains two stages. ${ }^{1)}$ In the first stage, desiliconization and dephosphorization are performed at low temperature and low basicity, and then the dephosphorization slag is poured out. In the second stage, decarburization is carried out in the same converter. After decarburization, the decarburization slag with high basicity is left in the furnace and reused in the next heat for dephosphorization, so that the lime consumption and slag amount can be greatly reduced.

In the dephosphorization process of hot metal with the NDSP, the mineralogical structure and viscosity of dephosphorization slag play an important role in dephosphorization capacity. In industrial production, the dephosphorization slag mainly consists of the $\mathrm{CaO}-\mathrm{FeO}-\mathrm{SiO}_{2}-\mathrm{MgO}-\mathrm{P}_{2} \mathrm{O}_{5}-$ $\mathrm{Al}_{2} \mathrm{O}_{3}-\mathrm{MnO}$ slag system, whose compositions are located within the $2 \mathrm{CaO} \cdot \mathrm{SiO}_{2}\left(\mathrm{C}_{2} \mathrm{~S}\right)$ saturated area of the $\mathrm{CaO}-$ $\mathrm{FeO}-\mathrm{SiO}_{2}$ phase diagram. It is well known that $\mathrm{C}_{2} \mathrm{~S}$ and $3 \mathrm{CaO} \cdot \mathrm{P}_{2} \mathrm{O}_{5}\left(\mathrm{C}_{3} \mathrm{P}\right)$ can form $2 \mathrm{CaO} \cdot \mathrm{SiO}_{2}-3 \mathrm{CaO} \cdot \mathrm{P}_{2} \mathrm{O}_{5}\left(\mathrm{C}_{2} \mathrm{~S}-\right.$ $\left.\mathrm{C}_{3} \mathrm{P}\right)$ solid solution in a large composition range of $\mathrm{P}_{2} \mathrm{O}_{5}{ }^{2}$ ) The distribution ratio of phosphorus between solid solution and liquid slag is very high, resulting in much lower phosphorus content in the liquid slag than that in the solid solu-

\footnotetext{
*Corresponding author: E-mail: yang_jian@t.shu.edu.cn
}

tion. This will promote a better removal of phosphorus from hot metal into the slag and improve the dephosphorization efficiency of hot metal.

The viscosity of slag not only determines whether the dephosphorization slag can be poured out smoothly at the end of the dephosphorization stage of the NDSP, but also has an important influence on the mass transfer between the slag and slag-hot metal interface in the dephosphorization process. The main factors affecting the slag viscosity are the temperature and slag compositions. It is reported that the slag viscosities increase with decreasing temperature for almost all the slags through the experimental measurement. ${ }^{3)}$ Park et al. studied the effect of $\mathrm{Al}_{2} \mathrm{O}_{3}$ on the viscosity of the $\mathrm{CaO}-\mathrm{SiO}_{2}-(\mathrm{MgO})-\mathrm{Al}_{2} \mathrm{O}_{3}$ slag system. ${ }^{4)}$ It was found that with increasing the $\mathrm{Al}_{2} \mathrm{O}_{3}$ content in the slag, the viscosity of the slag first increases and then decreases, which is ascribed to the amphoteric behavior of $\mathrm{Al}_{2} \mathrm{O}_{3}$ in the melt. Kim et al. reported that the viscosity of the slag with fixed basicity $\left(\mathrm{CaO} / \mathrm{SiO}_{2}\right)$ between 0.8 and 1.3 is increased with increasing the $\mathrm{Al}_{2} \mathrm{O}_{3}$ content due to the polymerization of the aluminate structures. ${ }^{5)}$ Wang et al. indicated that the viscosity of the $\mathrm{CaO}-\mathrm{SiO}_{2}-\mathrm{Al}_{2} \mathrm{O}_{3}-\mathrm{MgO}-\mathrm{Fe}_{\mathrm{t}} \mathrm{O}$ slag is also slightly increased with increasing the $\mathrm{Al}_{2} \mathrm{O}_{3}$ content and the $\mathrm{Al}^{3+}$ behaves as a network former with $\left[\mathrm{AlO}_{4}\right]$-tetrahedra increasing the degree of polymerization (DOP). ${ }^{6,7)}$ Besides, the viscosities of the slags of $\mathrm{CaO}-\mathrm{SiO}_{2}-\mathrm{Fe}_{\mathrm{t}} \mathrm{O}-\mathrm{Al}_{2} \mathrm{O}_{3}-\mathrm{MgO}$ and $\mathrm{CaO}-\mathrm{SiO}_{2}-\mathrm{Fe}_{\mathrm{t}} \mathrm{O}-\mathrm{Al}_{2} \mathrm{O}_{3}-\mathrm{MgO}-\mathrm{P}_{2} \mathrm{O}_{5}$ are decreased with 
increasing $\mathrm{Fe}_{t} \mathrm{O}$ content, respectively. This is because the DOP of the slags decreases with increasing the $\mathrm{Fe}_{t} \mathrm{O}$ content. $^{8)}$

There are some investigations on the mineralogical structure of converter slag, which correspond to the dephosphorization slag in the NDSP. ${ }^{9-14)}$ For example, Han et al. reported that the main mineralogical structure in the dephosphorization slag at the first deslagging in the BOF steelmaking process is $\mathrm{C}_{2} \mathrm{~S}$ and $\mathrm{C}_{2} \mathrm{~S}-\mathrm{C}_{3} \mathrm{P}$, which are favorable for dephosphorization. ${ }^{11)}$ Shu et al. investigated the effects of basicity, $\mathrm{MgO}$ and $\mathrm{MnO}$ on mineralogical phases of $\mathrm{CaO}-\mathrm{FeO}_{\mathrm{x}}-\mathrm{SiO}_{2}-\mathrm{P}_{2} \mathrm{O}_{5}$ slag after controlled cooling. It was found that the increase of basicity in the range of 1.3-2.0 promotes the crystallization of $\mathrm{CaO}-\mathrm{FeO}_{\mathrm{x}}-\mathrm{SiO}_{2}-\mathrm{P}_{2} \mathrm{O}_{5}$ slag and the increases of $\mathrm{MgO}$ and $\mathrm{MnO}$ contents promote the precipitation of $\mathrm{MgFe}_{2} \mathrm{O}_{4}$ and $\mathrm{MnFe}_{2} \mathrm{O}_{4}$, respectively. ${ }^{10)}$ Lin et al. also reported that the mineralogical phases in steelmaking slag cooled in the air are mainly the $\mathrm{nC}_{2} \mathrm{~S}-\mathrm{C}_{3} \mathrm{P}$ solid solution and spinel phase. ${ }^{9)}$ Besides, the effects of basicity on dephosphorization of hot metal with low basicity slag at $1653 \mathrm{~K}$ were investigated by the present authors. It was found that the phosphorus mainly exists in the form of $20 \mathrm{C}_{2} \mathrm{~S}-\mathrm{C}_{3} \mathrm{P}$ in the phosphorus(P)-rich phase of slag. ${ }^{12)}$

In recent years, some studies on the mass fraction of solid solution in the slag with the low basicity at the low temperature have also been carried out. ${ }^{14,15)} \mathrm{Xia}$ et al. found that the area of $\mathrm{C}_{2} \mathrm{~S}-\mathrm{C}_{3} \mathrm{P}$ increases quickly in the first 7 minutes, then changes little with the progress in dephosphorization of hot metal at $1673 \mathrm{~K} .{ }^{14)} \mathrm{Du}$ et al. reported that with the increase in $\mathrm{Na}_{2} \mathrm{O}$ content in the $\mathrm{CaO}-\mathrm{SiO}_{2}-\mathrm{Fe}_{2} \mathrm{O}_{3}-\mathrm{P}_{2} \mathrm{O}_{5}-$ $\mathrm{Na}_{2} \mathrm{O}$ slag system, the mass fraction of the solid solution is increased at various $\mathrm{P}_{2} \mathrm{O}_{5}$ contents. ${ }^{15)}$

It is very important for the NDSP that the dephosphorization can be efficiently conducted and the deslagging after dephosphorization can be smoothly carried out. The high basicity of slag is beneficial to dephosphorization but is deleterious to deslagging, while the high temperature is conducive to deslagging but is harmful for the dephosphorization. Therefore, in the present paper, the optimum dephosphorization temperature under about the same basicity can be obtained through the study of slag viscosity and dephosphorization behavior.

In this paper, the viscosity, structure, mineralogical phase and region proportion of dephosphorization slag in the NDSP with the low basicity of about 1.8 at the low temperature range of $1573 \mathrm{~K}-1723 \mathrm{~K}$ were investigated with the high-temperature laboratorial experiments. This low basicity slag was corresponding to the slag suitably used in the NDSP, which had a reasonable dephosphorization capacity and good flowability for smoothly intermediate deslagging. The activation energy for the viscous flow of the slag at different dephosphorization temperatures was calculated. The structures of dephosphorization slag at different temperatures were analyzed using Raman and FTIR spectroscopy. Moreover, the mineralogical phases of dephosphorization slag were analyzed using the Scanning Electron Microscopy-Energy Dispersive X-ray Spectroscopy (SEM-EDS). Besides, the changes in the proportion of P-rich region, Fe-rich region and liquid region of dephosphorization slag with the temperature at the range from $1573 \mathrm{~K}$ to $1673 \mathrm{~K}$ were also discussed.

\section{Experimental Procedure}

\subsection{Preparation of Dephosphorization Slag at Different End Temperatures of Dephosphorization}

In the present work, the decarburization slag reused for the next heat dephosphorization was prepared with analytical reagents $\mathrm{CaO}, \mathrm{FeO}, \mathrm{SiO}_{2}, \mathrm{MgO}, \mathrm{MnO}$ and $\mathrm{Ca}_{3}\left(\mathrm{PO}_{4}\right)_{2}$, which have similar compositions to the slag at the end of the industrial decarburization process. And then the produced decarburization slag with the chemical compositions of $(\mathrm{CaO})=45.6$ mass $\%,\left(\mathrm{SiO}_{2}\right)=13.9$ mass $\%,(\mathrm{~T} . \mathrm{Fe})=15.9$ $\operatorname{mass} \%,(\mathrm{MgO})=9.02 \operatorname{mass} \%,(\mathrm{MnO})=3.98$ mass $\%$ and $\left(\mathrm{P}_{2} \mathrm{O}_{5}\right)=3.03$ mass $\%$ was ground into powders and mixed evenly. The $300 \mathrm{~g}$ pig irons with the chemical compositions of $[\mathrm{C}]=4.07-4.35 \mathrm{mass} \%,[\mathrm{Si}]=0.35-0.44 \mathrm{mass} \%$, $[\mathrm{Mn}]=0.20-0.29$ mass $\%$ and $[\mathrm{P}]=0.2-0.25 \mathrm{mass} \%$ were prepared by premelting mixtures of pure iron, carbon blocks, ferrophosphorus, silicon and manganese powders in an alumina crucible using an induction furnace in vacuum condition. Then, about $21 \mathrm{~g}$ decarburization slag and 18 g $\mathrm{Fe}_{2} \mathrm{O}_{3}$ were mixed evenly and added into hot metal for dephosphorization at different temperatures. When the reaction time reached $15 \mathrm{~min}$, the crucible was quickly taken out of the resistance furnace and then quenched in water. The compositions of the slag and hot metal after dephosphorization are shown in Table 1. $\mathrm{R}_{2}$ is the mass ratio of $\mathrm{CaO}$ to $\mathrm{SiO}_{2}$. More details of experimental preparation can refer to our previous papers. ${ }^{12,16,17)}$

Table 1. Compositions of the slag and hot metal at the end of the dephosphorization stage.

\begin{tabular}{|c|c|c|c|c|c|c|c|c|c|c|c|c|c|c|c|}
\hline \multirow{2}{*}{ Sample } & $\mathrm{T}$ & T.Fe & $\mathrm{CaO}$ & $\mathrm{SiO}_{2}$ & $\mathrm{Al}_{2} \mathrm{O}_{3}$ & $\mathrm{MgO}$ & $\mathrm{MnO}$ & $\mathrm{P}_{2} \mathrm{O}_{5}$ & $\mathrm{R}_{2}$ & {$[\mathrm{C}]_{\mathrm{f}}$} & {$[\mathrm{Si}]_{\mathrm{f}}$} & {$[\mathrm{Mn}]_{\mathrm{f}}$} & {$[\mathrm{P}]_{\mathrm{f}}$} & De-Si & De-P \\
\hline & $\mathrm{K}$ & \multicolumn{12}{|c|}{$(\operatorname{mass} \%)$} & \multicolumn{2}{|c|}{$\%$} \\
\hline S1573 & 1573 & 33.3 & 26.2 & 11.8 & 1.38 & 5.00 & 3.22 & 1.93 & 2.22 & 3.91 & 0.055 & 0.139 & 0.165 & 85.2 & 17.9 \\
\hline S1598 & 1598 & 27.2 & 28.5 & 14.4 & 3.77 & 5.36 & 3.42 & 3.01 & 1.97 & 3.96 & 0.038 & 0.083 & 0.079 & 89.4 & 62.1 \\
\hline S1623 & 1623 & 26.0 & 27.6 & 14.5 & 5.57 & 5.02 & 3.84 & 3.76 & 1.91 & 3.81 & 0.033 & 0.080 & 0.069 & 92.2 & 71.5 \\
\hline S1648 & 1648 & 21.8 & 31.3 & 15.5 & 6.02 & 5.84 & 3.63 & 3.86 & 2.03 & 3.70 & 0.005 & 0.098 & 0.066 & 98.9 & 73.4 \\
\hline S1673 & 1673 & 18.2 & 30.6 & 16.4 & 10.4 & 5.60 & 4.05 & 4.07 & 1.86 & 3.74 & 0.007 & 0.105 & 0.091 & 98.1 & 58.1 \\
\hline $\mathrm{S} 1698$ & 1698 & 20.4 & 27.3 & 14.5 & 15.8 & 4.86 & 2.91 & 2.49 & 1.88 & 3.70 & 0.007 & 0.128 & 0.124 & 98.3 & 47.9 \\
\hline S1723 & 1723 & 17.4 & 26.9 & 14.6 & 20.5 & 4.57 & 3.27 & 2.49 & 1.85 & 3.64 & 0.008 & 0.119 & 0.156 & 97.9 & 23.5 \\
\hline
\end{tabular}




\subsection{Calculation of the Viscosity of Dephosphorization Slag}

It is difficult to measure the viscosity of the dephosphorization slag with the rotating cylinder viscometer because there is little slag left due to the small scale of the high-temperature experiment for the NDSP. The generated dephosphorization slag is mainly multiphase slag with a mixture of solid and liquid. Therefore, the viscosity of dephosphorization slag at each dephosphorization temperature is calculated by combining the Factsge 7.3 thermodynamic commercial software with the Einstein-Roscoe modeling equation. ${ }^{18-20)}$ It is assumed that the P-rich solid solution and metal oxide (RO) are distributed in diverse sizes of spherical particles. The viscosity of dephosphorization slag containing solid suspensions can be approximately described in Eq. (1).

$$
\eta=\eta_{0}(1-c)^{-2.5}
$$

where $\eta$ and $\eta_{0}$ are the viscosities of the solid-containing melt and the liquid melt, respectively. $c$ is the volume fraction of solid particles in the melt.

Because the density of the solid particles precipitated in the melt is uncertain, the solid mass fraction can be used instead of the $c$ value. The viscosity and mass fraction of liquid melt under the equilibrium condition can be evaluated using Factage 7.3, respectively.

As the iron in the slag mainly exists in the form of $\mathrm{FeO}^{14,17)}$ the T.Fe content in the slag is converted theoretically into the $\mathrm{FeO}$ content to calculate the slag viscosity.

\subsection{Analysis Method}

The Raman spectrum was measured by the Raman spectrometer (LabRAM HR evolution) with the excitation wavelength of $532 \mathrm{~nm}$, the lens of 50 times and the semiconductor laser of $10 \mathrm{mw}$ as the light source. The measurement frequency range was $200 \mathrm{~cm}^{-1}-2000 \mathrm{~cm}^{-1}$, and the wavenumber accuracy was $1 \mathrm{~cm}^{-1}$. FTIR spectroscopy (TENSOR 27) equipped with a $\mathrm{KBr}$ detector was used to analyze the structure of dephosphorization slags with a resolution of $1 \mathrm{~cm}^{-1}$ over the spectral range of $400 \mathrm{~cm}^{-1}-4000 \mathrm{~cm}^{-1}$. The sample of $2.0 \mathrm{mg}$ to be tested was mixed with $200 \mathrm{mg} \mathrm{KBr}$ reagent in an agate mortar and then pressed into a glass sheet with a diameter of 13 $\mathrm{mm}$ for measurement and analysis. The glass samples of dephosphorization slag were used for the analysis of the Raman and FTIR spectrum. The preparation of the glass samples of dephosphorization slags was as follows: Firstly, the dephosphorization slag powders under the reaction conditions were pressed with a tablet press and then placed in the laser heating gas suspension furnace (YE-YALG2P075, Changzhou Lantai Photoelectric Technology Co., Ltd). Secondly, they were blown up in a high purity argon (99.999\%) atmosphere and suspended. Meanwhile, they were melted under the condition of laser heating to raise the temperature to about $1973 \mathrm{~K}$. During the melting process, they were rotated at a high speed in the shape of ball to quickly achieve the melting uniform state. The melting time of each sample was about $10 \mathrm{~min}$, which can be set by monitoring with a computer. Lastly, the laser was turned off and the slag samples were quenched to the glass state by blowing with the argon gas. The $\mathrm{FeO}$ contents in the slag of the glass state were measured with the potassium dichromate titration method. The compositions of hot metal were analyzed using the direct reading spectrometer and the compositions of dephosphorization slag were analyzed by the X-ray fluorescence analysis. Besides, the morphology and compositions of the slag were characterized by SEM-EDS. The specific equipment introduction and sample preparation process can refer to our previous paper. ${ }^{16)}$

\section{Results and Discussion}

\subsection{Calculation of Activation Energy of Viscous Flow of the Slags at Different End Temperatures of Dephosphorization}

Figure 1 shows the effect of temperature on the viscosities of dephosphorization slags at different end temperatures of dephosphorization. With increasing the temperature, the viscosities of different slags first decrease rapidly and then decrease slowly. Because the number of structural units with viscous flow activation energy will increase with increasing temperature. At the same time, the thermal vibration of structural units is enhanced or the bonds of structural units split. The complex ions may disintegrate into smaller flow units, which leads to a decrease in viscosity. When the temperature is higher than $1723 \mathrm{~K}$, the viscosities of different slag samples increase with increasing the end temperature of dephosphorization. When the temperature is lower than $1723 \mathrm{~K}$, with decreasing temperature, the viscosities of S1573 and S1598 increase rapidly, and the viscosity of S1573 gradually becomes the largest.

Because when the temperature is higher than $1723 \mathrm{~K}$, the slags at different end temperatures of dephosphorization are close to the glass state. The $\mathrm{FeO}$ and $\mathrm{Al}_{2} \mathrm{O}_{3}$ contents, as well as the value of basicity of the slag, have a great important influence on the slag viscosity.

With increasing the end temperature of dephosphorization, the T.Fe content in slag is decreased and the $\mathrm{Al}_{2} \mathrm{O}_{3}$ content is increased. The T.Fe content in slag is mainly determined by the amount of $\mathrm{FeO}$ content in slag reacting with the $\mathrm{C}$ and $\mathrm{Si}$ in hot metal. When the end temperature of dephosphorization is high, the reaction between $\mathrm{FeO}$ in the slag and $\mathrm{C}$ or $\mathrm{Si}$ in the hot metal is promoted, and $\mathrm{FeO}$ content in the slag decreases greatly. Therefore, with increasing the end temperature of dephosphorization, the T.Fe content in slag is decreased. Besides, with increasing the end temperature of dephosphorization, the reaction between the slag and alumina crucible is promoted, resulting in the increase in the $\mathrm{Al}_{2} \mathrm{O}_{3}$ content of slag. With increasing the end temperature of dephosphorization, the reaction between $\mathrm{FeO}$ in the slag and $\mathrm{Si}$ in the hot metal is also promoted and the $\mathrm{Si}$ content decreases as shown in Table 1. Thus the $\mathrm{SiO}_{2}$ content of slag rises and basicity drops.

The increase of basicity and $\mathrm{FeO}$ content, as well as the decrease of $\mathrm{Al}_{2} \mathrm{O}_{3}$ content in the slag can reduce the DOP of the slag, thus reducing the slag viscosity. ${ }^{21-23)}$ Therefore, when the temperature is higher than $1723 \mathrm{~K}$, the viscosities of different slags increase with increasing the end temperature of dephosphorization. When the temperature is lower than $1723 \mathrm{~K}$, all the dephosphorization slags are in a state of solid-liquid coexistence. The melting point of different 


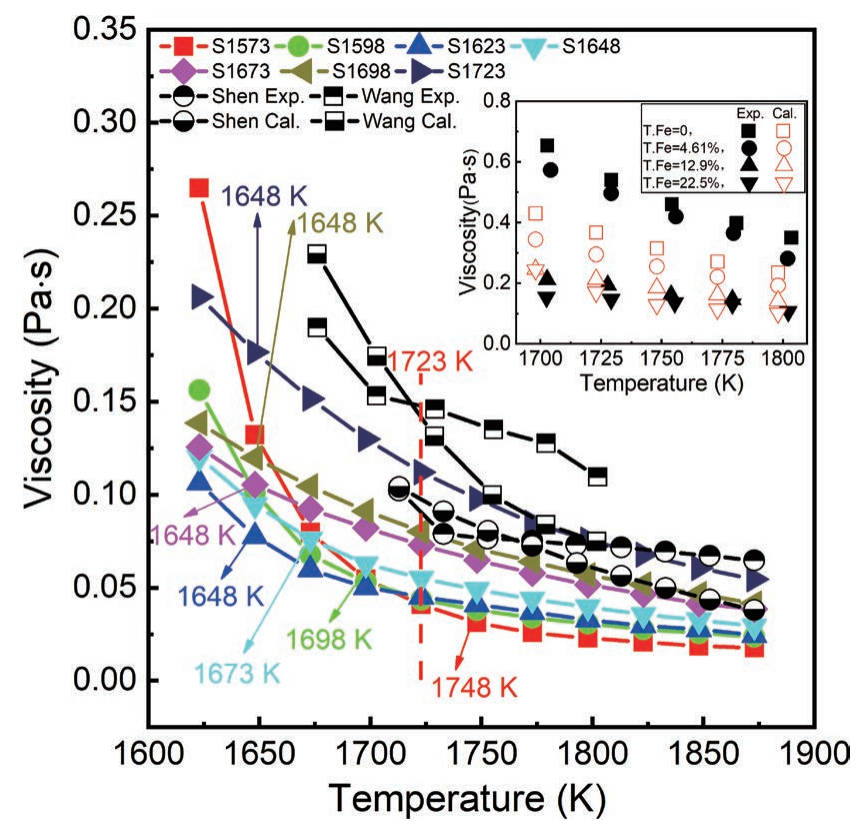

Fig. 1. Effect of the temperature on the viscosities of the different dephosphorization slags and comparison between the present calculated results and the previous researchers' experimental results.

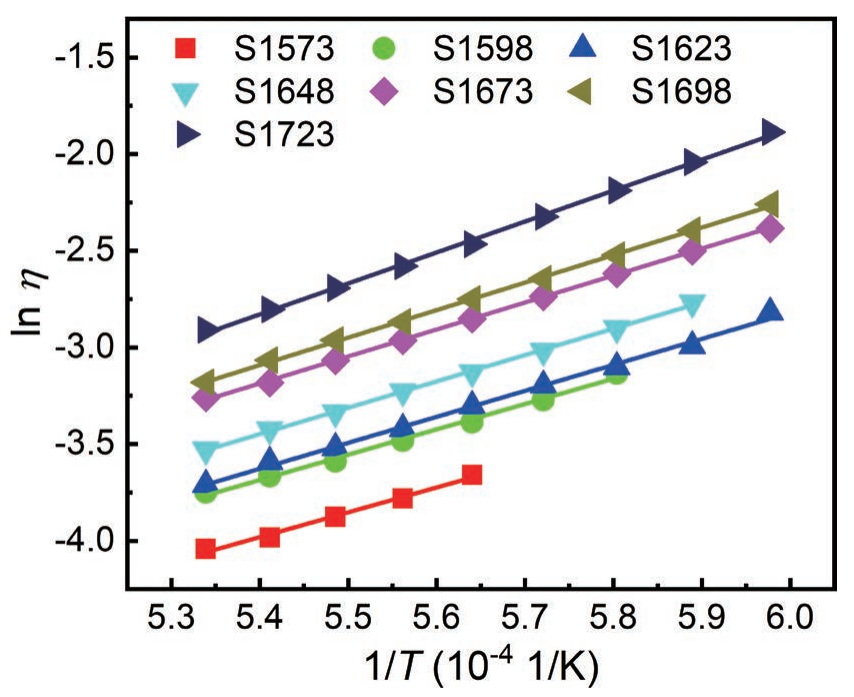

Fig. 2. Variation of the natural logarithm of the viscosity of dephosphorization slag with reciprocal of temperature at different end temperatures of dephosphorization.

slag samples plays a dominant role in the viscosity. The higher is the melting point of slag, and the greater is the undercooling degree, thus the more solid crystals should be precipitated, which makes the slag viscosity increase greatly.

With decreasing the end temperature of dephosphorization, the melting point of slag increases, as shown in Fig. 11 in Section 3.4. Therefore, the slag S1573 has the undercooling degree of the maximum value. In Fig. 1, there is an inflection point at which the value of viscosity changes largely and the molten slag becomes non-Newtonian in behaviour when temperature is below the temperature of the inflection point. ${ }^{24)}$ The viscosity inflection point for slag S1573 appears at the temperature of $1748 \mathrm{~K}$, which can be considered as the crystallization temperature..$^{724,25)}$ The viscosity inflection points of other slags are also shown in Fig. 1. It can be found that the inflection points of S1573 and S1598 are higher than those of other slags. As a result, when the temperature is lower than $1723 \mathrm{~K}$, with decreasing the temperature, the viscosities of S1573 and S1598 increase rapidly, and S1573 gradually has the viscosity of the largest value.

The temperature variation of the viscosity of $\mathrm{CaO}-$ $\mathrm{MgO}-\mathrm{SiO}_{2}-\mathrm{Al}_{2} \mathrm{O}_{3}-\mathrm{FeO}$ slag measured by Shen et al. and the viscosity of $\mathrm{CaO}-\mathrm{MgO}-\mathrm{SiO}_{2}-\mathrm{Al}_{2} \mathrm{O}_{3}-\mathrm{Fe}_{\mathrm{t}} \mathrm{O}-\mathrm{P}_{2} \mathrm{O}_{5}$ slag measured by Wang et al. are shown in Fig. 1. We calculated viscosities for the slag with the same compositions in the experiments of Shen et al.'s and Wang et al.'s from combining the Factsge7.3 thermodynamic commercial software with the Einstein-Roscoe modeling equation. The calculated results are also presented in Fig. 1 with "wang cal." and "shen cal." for comparison. ${ }^{8,21)}$ Although there are some differences of the viscosities between the calculated and the experimental values, both variations in viscosity with temperature have the similar trend. In addition, the variation of the viscosity of slag with temperature at different T.Fe contents is also shown in the upper right corner of Fig. 1. The black solid marks are the experimental values of Wang et al.'s, ${ }^{8)}$ and the red hollow marks are the calculated values using this model. It can be seen that the trends of the influence of T.Fe content on the slag viscosity are consistent between the calculated and experimental results. The slag viscosity is decreased with increasing the T.Fe content. Therefore, it is feasible to use this model to study the variation trend of the slag viscosity with the similar slag compositions.

The viscosity measured by Wang et al. is higher than those of the dephosphorization slags calculated in the present paper. This is mainly because that the basicities of slags in the present paper are higher. The viscosity of the slag measured by Shen et al. is slightly higher than those of the dephosphorization slags in this paper, because the $\mathrm{FeO}$ content in their slag is lower than that in the present paper.

It can be seen from Fig. 1 that the inflection point temperatures corresponding to the homogeneous slag of the different slags are different. When the temperature is higher than the inflection point temperature, the slag will exist in the form of homogeneous slag, and the viscosity will follow the law of Newtonian viscous liquid. The activation energy of silicate-containing melt can be obtained with the Arrhenius equation as shown in Eq. (2).

$$
\eta=A \times \exp \left(E_{\eta} / R T\right)
$$

where $A$ is constant, $E_{\eta}\left(\mathrm{kJ} \cdot \mathrm{mol}^{-1}\right)$ represents the activation energy of viscous flow, $R\left(\mathrm{~kJ} \cdot \mathrm{kg}^{-1} \cdot \mathrm{mol}^{-1}\right)$ is the gas constant, and $T(\mathrm{~K})$ is the absolute temperature.

The activation energy of viscous flow represents the energy that the viscous flow unit of slag can overcome the friction resistance during moving. If the structure of the viscous flow unit of slag is not changed, then the activation energy will remain unchanged. Unless the characteristics of main polymerization units change, the value of activation energy is constant for a certain slag. The activation energy value can be evaluated according to the slope of linear fitting between the natural logarithm of viscosity and the reciprocal of temperature. Figure 2 shows the variation of the natural 
logarithm of the viscosity of different dephosphorization slags with reciprocal of temperature. The activation energy of different dephosphorization slags can be obtained through the slope of the linear fitting, as shown in Table 2. It can be seen that with increasing the end temperature of dephosphorization, the activation energy of the corresponding slag is increased. It also shows that more complex structural units are formed in the slag at a higher end temperature of dephosphorization, which increases the activation energy.

To test the reproducibility of the FactSage 7.3 viscosity model for the present multi-component system, the values of activation energy of the similar slag compositions are also predicted using the present calculation method. The comparison of the experimental values of activation energy measured by Wang et al. and the corresponding calculated values using present calculation method in different T.Fe contents of slag are shown in Fig. 3. The calculated values are little lower than the measured ones, and they are both decreased with increasing the T.Fe content in slag. Therefore, it is verified to predict the change in the activation energy of the dephosphorization slag using the present calculation method.

\subsection{Structure Analysis of Dephosphorization Slag at Different End Temperatures of Dephosphorization by Raman and FTIR Spectroscopy}

According to the determination results of $\mathrm{FeO}$ contents in dephosphorization slags of the glass state, the corresponding $\mathrm{FeO}$ contents decrease by $75 \%$, and the rest of iron mainly exists in the form of $\mathrm{Fe}_{2} \mathrm{O}_{3}$. In the previous studies by Shen et al. and Wang et al., both $\mathrm{FeO}$ and $\mathrm{Fe}_{2} \mathrm{O}_{3}$ can decrease the DOP of the slag through the microstructure analysis. Therefore, although part of $\mathrm{FeO}$ in glass sample is

Table 2. Activation energy of different dephosphorization slags.

\begin{tabular}{cccccccc}
\hline Sample & S1573 & S1598 & S1623 & S1648 & S1673 & S1698 & S1723 \\
\hline $\mathrm{E}_{\eta}\left(\mathrm{kJ} \cdot \mathrm{mol}^{-1}\right)$ & 106.8 & 108.9 & 111.7 & 113.3 & 116.1 & 118.3 & 133.1 \\
\hline
\end{tabular}

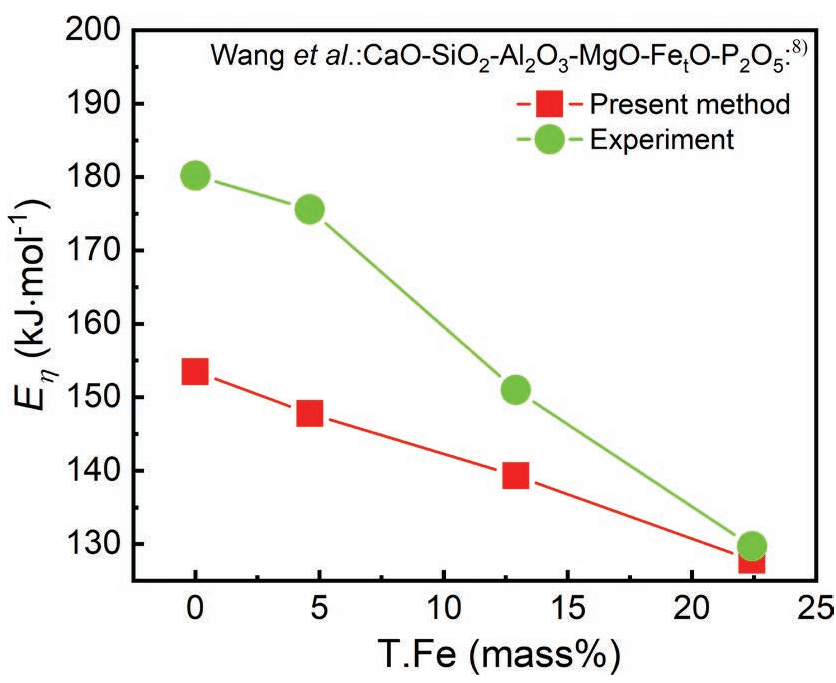

Fig. 3. Comparison of the experimental values of activation energy measured by Wang et al. and the corresponding calculated values using present calculation method in different T.Fe contents of slag. (Online version in color.) oxidized, the influence of the different end temperatures of dephosphorization on the DOP or the viscosity of the slag at the different iron redox states are simiar. ${ }^{8,21)}$

Figure 4 shows the Raman spectra for glass samples of the dephosphorization slag at different end temperatures of dephosphorization. All the original room temperature Raman spectra were smoothed firstly, and then the baselines were subtracted. There were large envelope peaks in the low-

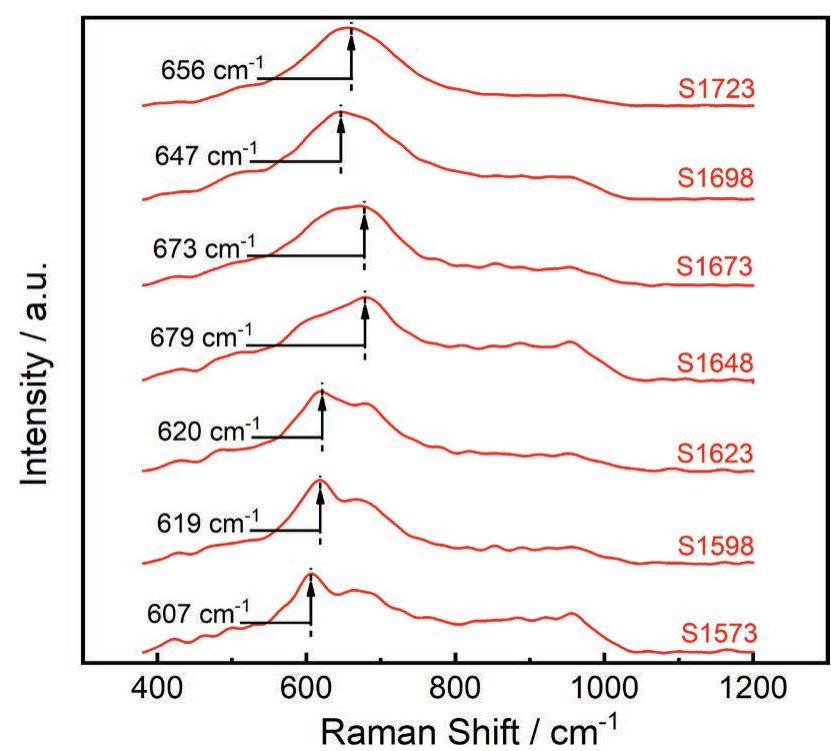

Fig. 4. Raman spectra for the glass samples of the dephosphorization slag at different end temperatures of dephosphorization. (Online version in color.)

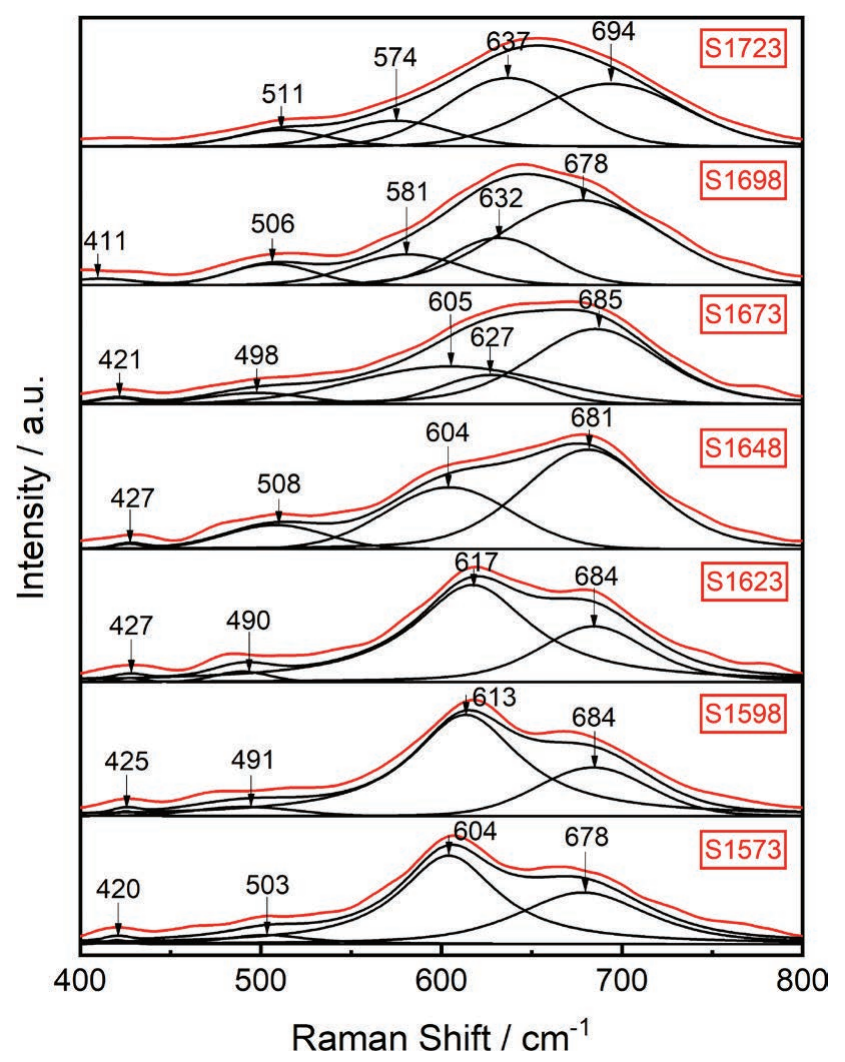

Fig. 5. Deconvoluted Raman spectra for glass samples of the dephosphorization slags at different end temperatures of dephosphorization in the low-frequency range. (Online version in color.) 
frequency region of $400-800 \mathrm{~cm}^{-1}$ and some bands of weak intensities near 850 , and $950 \mathrm{~cm}^{-1}$. The $\left[\mathrm{SiO}_{4}\right]$-tetrahedron peaks corresponding to the high-frequency region of $800-1200 \mathrm{~cm}^{-1}$ are relatively weak. These phenomena are consistent with those results reported by Jung et al. and Wang et al. ${ }^{8,26)}$ Jung et al. explained that the interconnection of some iron ions with the majority of the $\left[\mathrm{SiO}_{4}\right]$-tetrahedral structures depletes the $\left[\mathrm{SiO}_{4}\right]$-tetrahedral network structure so that the $\mathrm{Si}-\mathrm{O}$ vibration spectra are weakened. The central Raman shifts of these peaks are changed from $607 \mathrm{~cm}^{-1}$ to $679 \mathrm{~cm}^{-1}$ with increasing the end temperature of dephosphorization, indicating that the DOP of the $\left[\mathrm{FeO}_{4}\right]$-tetrahedra network structure is increased. ${ }^{8)}$

For further comparative analysis, the Raman spectra are divided into low-frequency $\left(400-800 \mathrm{~cm}^{-1}\right)$ and highfrequency (800-1 $200 \mathrm{~cm}^{-1}$ ) ranges, which are deconvoluted by the fitting method of Gaussian and Loren line fitting using PeakFit v4.12 software, respectively. Figure 5 shows the deconvoluted Raman spectra for glass samples of the dephosphorization slags at different end temperatures of dephosphorization in the low-frequency range. The structural units corresponding to Raman shifts in dephosphorization slag at the different end temperatures of dephosphorization are shown in Table 3. The peaks at about $600 \mathrm{~cm}^{-1}$ and $680 \mathrm{~cm}^{-1}$ correspond to $\left[\mathrm{FeO}_{6}\right]$-octahedra and $\left[\mathrm{FeO}_{4}\right]$-tetrahedra. ${ }^{26-29)}$ The peaks near $630 \mathrm{~cm}^{-1}$ can be considered to correspond to $\left[\mathrm{AlO}_{4}\right]$-tetrahedra, ${ }^{8,26)}$ but there is no fitting peak near $630 \mathrm{~cm}^{-1}$ in S1573, S1598, S1623 and $\mathrm{S} 1673$ because of the low $\mathrm{Al}_{2} \mathrm{O}_{3}$ content in the slag. With increasing the end temperature of dephosphorization, the area fraction of network modifier $\left[\mathrm{FeO}_{6}\right]$-octahedra tends to decrease, while those of network formers $\left[\mathrm{FeO}_{4}\right]$-tetrahedra and $\left[\mathrm{AlO}_{4}\right]$-tetrahedra tend to increase. The units of $\left[\mathrm{AlO}_{4}\right]$ and $\left[\mathrm{SiO}_{4}\right]$ tend to combine to form the reticular structural units, thus increasing the slag viscosity.

The deconvoluted Raman spectra for glass samples of the dephosphorization slags at different end temperatures of dephosphorization in the high-frequency range is shown in Fig. 6. The structural units corresponding to Raman shifts are also shown in Table 3 . In the $\left[\mathrm{SiO}_{4}\right]$-tetrahedron stretching range, the $\left[\mathrm{SiO}_{4}\right]$-tetrahedron structures unit with bridge oxygen numbers of $0,1,2$ and 3 of $Q^{0}, Q^{1}, Q^{2}$ and $Q^{3}$ appear near $850 \mathrm{~cm}^{-1}, 900 \mathrm{~cm}^{-1}, 950 \mathrm{~cm}^{-1}$ and 1080 $\mathrm{cm}^{-1}$, respectively. ${ }^{30)}$ According to the previous studies by Wong et al. and Wang et al., the peaks near 940, 1000 and $1140 \mathrm{~cm}^{-1}$ are $\mathrm{P}-\mathrm{O}-\mathrm{Ca}, \mathrm{P}-\mathrm{O}-\mathrm{P}$ and $\mathrm{P}-\mathrm{O}-\mathrm{Si}$ vibrations. ${ }^{31,32)}$

When a large number of non-bridging oxygen ions and the basic oxides of $\mathrm{CaO}, \mathrm{MgO}$ and $\mathrm{FeO}$ containing free oxygen ions exist in the slag, the reticular structural units will be decomposed into dimer and monomer structure unit, which will reduce the slag viscosity. Therefore, the amount of Non-Bridging Oxygen per Silicon (NBO/Si) is very important to the viscous flow activation energy of slag. The mole fraction of different structural units can be calculated by the area fraction of each structural unit in $\left[\mathrm{SiO}_{4}\right]$-tetrahedron in Eq. (3). The $\mathrm{NBO} / \mathrm{Si}$ in slag can be further calculated in Eq. (4). ${ }^{37)}$

$$
X_{i}=S_{i} \cdot A_{i}
$$

$$
\mathrm{NBO} / \mathrm{Si}=\sum X_{i}(4-i)
$$

where $X i$ is the mole fraction of $\left[\mathrm{SiO}_{4}\right]$-tetrahedral structure unit $\left(Q^{\mathrm{i}}\right)$ with the bridge oxygen numbers of i. $S_{i}$ is the Raman scattering coefficient of $Q^{\mathrm{i}}$. The Raman scattering coefficients of $Q^{0}, Q^{1}, Q^{2}$ and $Q^{3}$ are 1, 0.514, 0.242 and 0.09 , respectively. ${ }^{38)} A_{i}$ is the area fraction of the corresponding fitting spectra peak of $Q^{\mathrm{i}}$.

Figure 7 shows NBO/Si and area fractions of $\left(Q^{0}+Q^{1}\right)$ and $\left(Q^{2}+Q^{3}\right)$ structure units for glass samples of dephosphorization slags at different end temperatures of dephosphorization. It can be seen that the area fraction of the $\left(Q^{0}+\right.$ $\left.Q^{1}\right)$ structure units and the value of $\mathrm{NBO} / \mathrm{Si}$ are decreased with increasing the temperature, while the area fraction of $\left(Q^{2}+Q^{3}\right)$ structure units is increased. With increasing the dephosphorization temperature, the content of $\mathrm{Al}_{2} \mathrm{O}_{3}$ in the dephosphorization slag increases gradually, which results in the increase of the area fraction of $\left(Q^{2}+Q^{3}\right)$ in the slag. However, the increase of $\mathrm{Al}_{2} \mathrm{O}_{3}$ and the decrease of $\mathrm{FeO}$ content in slag can easily reduce the total amount of $\left(Q^{0}+\right.$ $Q^{1}$ ) structure units. ${ }^{7,822)}$ Therefore, the total area fraction

Table 3. Analysis of structural units corresponding to Raman shifts in dephosphorization slag at different end tempera-

\begin{tabular}{|c|c|c|c|c|c|c|c|c|}
\hline Sample & S1573 & S1598 & S1623 & S1648 & S1673 & S1698 & S1723 & Raman Assignments \\
\hline \multirow{12}{*}{$\begin{array}{l}\text { Raman shift } \\
\qquad\left(\mathrm{cm}^{-1}\right)\end{array}$} & 420 & 425 & 427 & 427 & 421 & 411 & - & rocking vibration of $\mathrm{Si}-\mathrm{O}-\mathrm{Si}^{33,34)}$ \\
\hline & 503 & 491 & 490 & 508 & 498 & 506 & 511 & vibration of $\mathrm{Al}-\mathrm{O}-\mathrm{Si}^{35,36)}$ \\
\hline & 604 & 613 & 617 & 604 & 605 & 581 & 574 & octahedra stretching vibration of $\left[\mathrm{FeO}_{6}\right] .^{26-29)}$ \\
\hline & - & - & - & - & 627 & 632 & 637 & tetrahedra stretching vibration of $\left[\mathrm{AlO}_{4}\right]^{8,26)}$ \\
\hline & 678 & 684 & 684 & 681 & 685 & 678 & 694 & tetrahedra stretching vibration of $\left[\mathrm{FeO}_{4}\right] .{ }^{26-29)}$ \\
\hline & 840 & 855 & 875 & 852 & 857 & 856 & 858 & {$\left[\mathrm{SiO}_{4}\right]$ with zero bridging oxygen. ${ }^{30)}\left(Q^{0}\right)$} \\
\hline & 883 & 888 & 915 & 885 & 888 & 888 & 893 & {$\left[\mathrm{SiO}_{4}\right]$ with one bridging oxygen. ${ }^{30)}\left(Q^{1}\right)$} \\
\hline & 958 & 966 & 989 & 954 & 957 & 958 & 974 & {$\left[\mathrm{SiO}_{4}\right]$ with two bridging oxygen. ${ }^{30)}\left(Q^{2}\right)$} \\
\hline & 1098 & 1086 & 1092 & 1100 & 1095 & 1098 & 1069 & {$\left[\mathrm{SiO}_{4}\right]$ with three bridging oxygen. ${ }^{30)}\left(Q^{3}\right)$} \\
\hline & 922 & 925 & 952 & 917 & 923 & 924 & 941 & $\mathrm{P}-\mathrm{O}-\mathrm{Ca}{ }^{32)}$ \\
\hline & 994 & 1011 & 1044 & 991 & 992 & 993 & 1003 & $\mathrm{P}-\mathrm{O}-\mathrm{P}^{31)}$ \\
\hline & 1166 & 1160 & 1155 & 1169 & 1152 & 1153 & 1144 & $\mathrm{P}-\mathrm{O}-\mathrm{Si}^{31,32)}$ \\
\hline
\end{tabular}
tures of dephosphorization. 


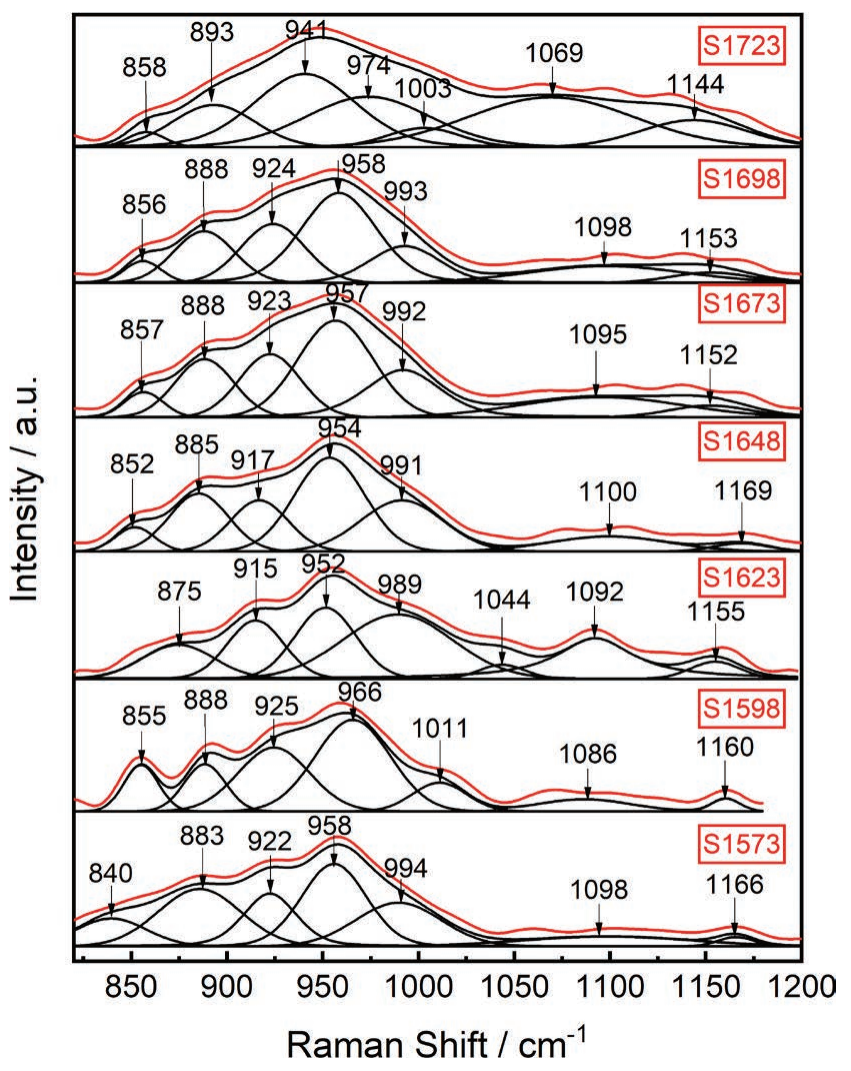

Fig. 6. Deconvoluted Raman spectra for glass samples of the dephosphorization slags at different end temperatures of dephosphorization in the high-frequency range. (Online version in color.)

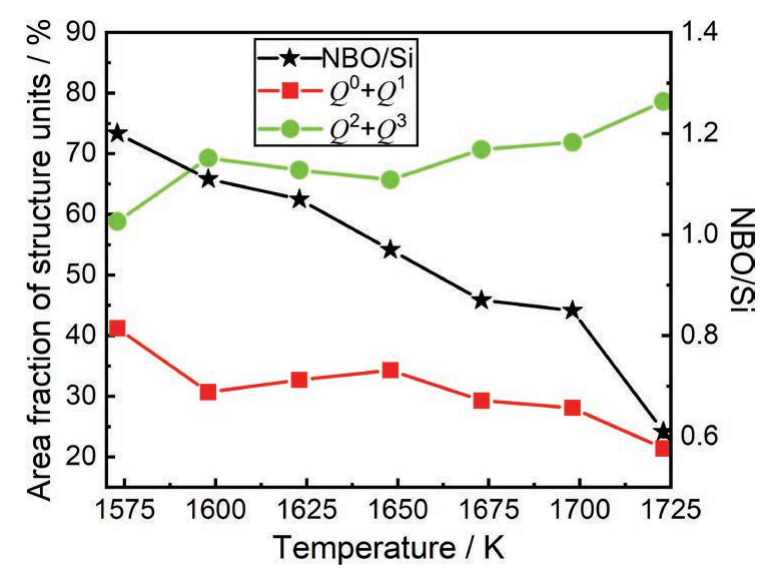

Fig. 7. $\mathrm{NBO} / \mathrm{Si}$ and area fractions of $\left(Q^{0}+Q^{1}\right)$ and $\left(Q^{2}+Q^{3}\right)$ structure units for glass samples of dephosphorization slags at different end temperatures of dephosphorization. (Online version in color.)

of $\left(Q^{0}+Q^{1}\right)$ structure units decreases with the increase in the dephosphorization temperature. The value of NBO/Si decreases with increasing the dephosphorization temperature, which further indicates that the DOP of the dephosphorization slag increases. These results show that when the basicity of slag is about 1.85 , the $\mathrm{Al}_{2} \mathrm{O}_{3}$ in the dephosphorization slag mainly exists as a network former, and $\mathrm{FeO}$ mainly exists as a network modifier. It also explains why the viscous flow activation energy of dephosphorization slag increases with increasing the dephosphorization temperature in section 3.1 .

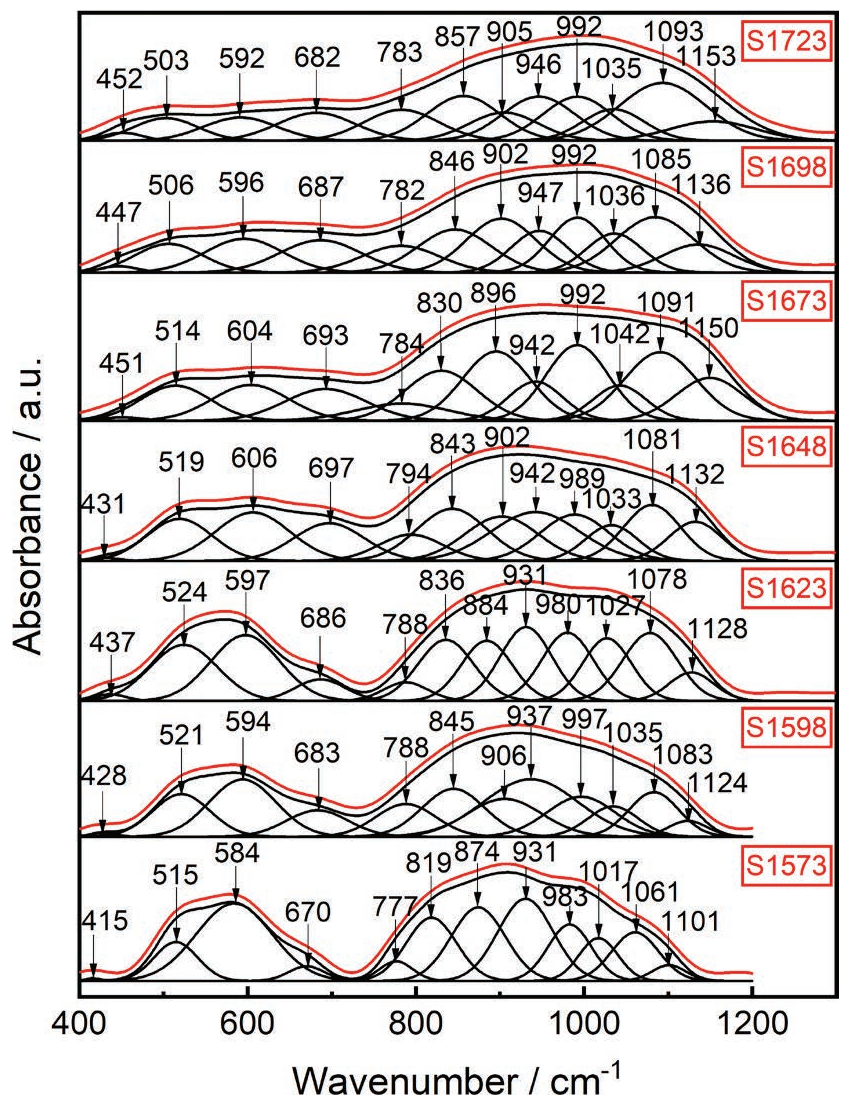

Fig. 8. Deconvoluted FTIR absorption spectra for glass samples of the dephosphorization slags at different end temperatures of dephosphorization. (Online version in color.)

Figure 8 shows the deconvoluted FTIR absorption spectra for glass samples of the dephosphorization slags at different end temperatures of dephosphorization. As shown in Fig. 8, from the red lines which are the original FTIR absorption spectra subtracted baseline, one can see that there are two broad absorption bands in the low-frequency and highfrequency ranges, respectively. With increasing the end temperature of dephosphorization, the width and intensity of the peak in the low-frequency range decrease gradually, while in the high-frequency range the opposite is true. It indicates that the increased $\mathrm{Al}_{2} \mathrm{O}_{3}$ content and decreased $\mathrm{FeO}$ content in slag due to the increasing dephosphorization temperature can increase the DOP of $\left[\mathrm{SiO}_{4}\right]$-tetrahedral units.

The structural units corresponding to FTIR wavenumber in dephosphorization slag at different end temperatures of dephosphorization are shown in Table 4. According to previous studies, ${ }^{34,39,40)}$ the absorption peaks near 830 , 890,980 and $1080 \mathrm{~cm}^{-1}$ can be attributed to asymmetric stretch vibrations of $Q^{0}, Q^{1}, Q^{2}$ and $Q^{3}$ tetrahedral units, respectively. The peaks near $440 \mathrm{~cm}^{-1}$ and $500 \mathrm{~cm}^{-1}$ correspond to the $\mathrm{Si}-\mathrm{O}-\mathrm{Si}$ and $\mathrm{Si}-\mathrm{O}-\mathrm{Al}$ rocking bands, ${ }^{8,34)}$ the peaks at about $580 \mathrm{~cm}^{-1}$ and $680 \mathrm{~cm}^{-1}$ correspond to $\left[\mathrm{FeO}_{6}\right]$-octahedra and $\left[\mathrm{FeO}_{4}\right]$-tetrahedra, ${ }^{8)}$ and the peaks near 940, 1020 and $1130 \mathrm{~cm}^{-1}$ can be attributed to the $\mathrm{P}-\mathrm{O}-\mathrm{Ca}, \mathrm{P}-\mathrm{O}-\mathrm{P}$ and $\mathrm{P}-\mathrm{O}-\mathrm{Si}$ vibrations, respectively. ${ }^{31,32,34)}$ It should be noticed that the relative intensities of peaks near $780 \mathrm{~cm}^{-1}$ corresponding to $\left[\mathrm{AlO}_{4}\right]$-structural units found in S1698 and S1723 samples are slightly stronger. ${ }^{41)}$ This indicates that the more [AlO4]-structural units are formed due to the increase in $\mathrm{Al}_{2} \mathrm{O}_{3}$ as a network former. It can be 
Table 4. Analysis of structural units corresponding to FTIR wavenumber for glass samples of dephosphorization slags at different dephosphorization temperatures.

\begin{tabular}{|c|c|c|c|c|c|c|c|c|}
\hline Sample & S1573 & $\mathrm{S} 1598$ & S1623 & S1648 & S1673 & S1698 & S1723 & Raman Assignments \\
\hline \multirow{12}{*}{$\begin{array}{l}\text { Wavenumber } \\
\qquad\left(\mathrm{cm}^{-1}\right)\end{array}$} & 415 & 428 & 437 & 431 & 451 & 447 & 452 & rocking vibration of $\mathrm{Si}-\mathrm{O}-\mathrm{Si}^{34)}$ \\
\hline & 515 & 521 & 524 & 519 & 514 & 506 & 503 & vibration of $\mathrm{Al}-\mathrm{O}-\mathrm{Si}^{8}{ }^{8}$ \\
\hline & 584 & 594 & 597 & 606 & 604 & 596 & 592 & octahedra stretching vibration of $\left[\mathrm{FeO}_{6}\right]^{8)}$ \\
\hline & 670 & 683 & 686 & 697 & 693 & 687 & 682 & tetrahedra stretching vibration of $\left[\mathrm{FeO}_{4}\right] .{ }^{8)}$ \\
\hline & 777 & 788 & 788 & 794 & 784 & 782 & 783 & tetrahedra stretching vibration of $\left[\mathrm{AlO}_{4}\right]_{.}^{41)}$ \\
\hline & 819 & 845 & 836 & 843 & 830 & 846 & 857 & $Q^{0.34,39,40)}$ \\
\hline & 874 & 906 & 884 & 902 & 896 & 902 & 905 & $Q^{1.34,39,40)}$ \\
\hline & 983 & 997 & 980 & 989 & 992 & 992 & 992 & $Q^{2} \cdot{ }^{34,39,40)}$ \\
\hline & 1061 & 1083 & 1078 & 1081 & 1091 & 1085 & 1093 & $Q^{3.34,39,40)}$ \\
\hline & 931 & 937 & 931 & 942 & 942 & 947 & 946 & $\mathrm{P}-\mathrm{O}-\mathrm{Ca} \cdot{ }^{31,32,34)}$ \\
\hline & 1017 & 1035 & 1027 & 1033 & 1042 & 1036 & 1035 & $\mathrm{P}-\mathrm{O}-\mathrm{P}^{31,32,34)}$ \\
\hline & 1101 & 1124 & 1128 & 1132 & 1150 & 1136 & 1153 & $\mathrm{P}-\mathrm{O}-\mathrm{Si}^{31,32,34)}$ \\
\hline
\end{tabular}

inferred that with the increase of $\mathrm{Al}_{2} \mathrm{O}_{3}$ content, $\left[\mathrm{AlO}_{4}\right]$ and $\left[\mathrm{SiO}_{4}\right]$ in slag will further form a more complex network structure. Therefore, the higher is the dephosphorization temperature, the higher is the viscous flow activation energy of the dephosphorization slag. It is consistent with the results of Raman analysis.

\subsection{Mineralogical Phases of Dephosphorization Slag Observed with SEM-EDS}

According to the results of Raman and infrared spectrum analysis of dephosphorization slag in section 3.2, it can be deduced that when the $\mathrm{Al}_{2} \mathrm{O}_{3}$ content in the slag is higher, the microstructure of dephosphorization slag will be changed greatly, and the $\left[\mathrm{AlO}_{4}\right]$ tetrahedral unit will combine with $\left[\mathrm{SiO}_{4}\right]$ tetrahedral unit to form more complex substances. Besides, Wang et al. reported that with the increase of $\mathrm{Al}_{2} \mathrm{O}_{3}$ content in slag, $\left[\mathrm{AlO}_{4}\right]$ tetrahedral unit and $\left[\mathrm{FeO}_{4}\right]$ tetrahedral unit can combine to promote phase transformation from $\mathrm{MgFe}_{2} \mathrm{O}_{4}$ spinel to $\mathrm{MgAlFeO}_{4}$ spinel. ${ }^{7)}$

Figure 9 shows SEM images and XRD analysis results of dephosphorization slag samples of S1573, S1598, S1623, S1648, S1673 and S1723. The crystalline phases in XRD image in Fig. 9 are assigned with the principle of threestrong peaks. The intensities of some corresponding peaks are so weak that they are not shown in the figure. Because the compositions and mineralogical phases of dephosphorization slag at $1698 \mathrm{~K}$ are similar to those at $1723 \mathrm{~K}$, its results of SEM image and XRD analysis result are omitted in Fig. 9. The phases of dephosphorization slag at 1573 $\mathrm{K}-1673 \mathrm{~K}$ are similar, mainly containing P-rich region A, $\mathrm{Fe}$-rich region $\mathrm{B}$ and liquid region $\mathrm{C}$. The dephosphorization slag at $1723 \mathrm{~K}$ mainly contains metal oxide phase and matrix phase.

Therefore, in the present work, the EDS analysis results corresponding to different regions of the dephosphorization slag of $\mathrm{S} 1648$ with low $\mathrm{Al}_{2} \mathrm{O}_{3}$ content and $\mathrm{S} 1723$ with high $\mathrm{Al}_{2} \mathrm{O}_{3}$ content as shown in Table 5 are taken as representative samples for further analysis. It can be deduced that P-rich region A mainly contains $\mathrm{nC}_{2} \mathrm{~S}-\mathrm{C}_{3} \mathrm{P}$, $\mathrm{C}_{2} \mathrm{~S}, \mathrm{Ca}_{3} \mathrm{Mg}\left(\mathrm{SiO}_{4}\right)_{2}, \mathrm{Ca}(\mathrm{Mg}, \mathrm{Fe}) \mathrm{Si}_{2} \mathrm{O}_{6}, \mathrm{Ca}_{2} \mathrm{Fe}_{2} \mathrm{O}_{5}$. Fe-rich region $\mathrm{B}$ is mainly composed of $(\mathrm{MgO})_{\mathrm{x}}(\mathrm{FeO})_{1-\mathrm{x}},(\mathrm{Mn}, \mathrm{Mg})$ $\mathrm{Fe}_{2} \mathrm{O}_{4}$. From the compositions of region $\mathrm{B}$ in $\mathrm{S} 1648$ and $\mathrm{S} 1723$ in Table 5, it can be found that with the increase of the $\mathrm{Al}_{2} \mathrm{O}_{3}$ content in dephosphorization slag, the $\mathrm{Al}, \mathrm{Si}$ and $\mathrm{Ca}$ contents in region $\mathrm{B}$ gradually increase. Therefore, it can be speculated that a small amount of $\mathrm{Fe}_{2} \mathrm{SiO}_{4}$, $\mathrm{MgAl}_{2} \mathrm{O}_{4}$ and $\mathrm{Ca}_{3} \mathrm{Mg}\left(\mathrm{SiO}_{4}\right)_{2}$ may exist in region $\mathrm{B}$ which looks composed of a single crystalline phase as shown in Fig. 9. The liquid region $\mathrm{C}$ mainly exists in a glassy state containing a small amount of $\mathrm{Ca}_{3}\left(\mathrm{PO}_{4}\right)_{2}$. However, the slag of S1723 is mainly composed of complex structure regions $\mathrm{A}-1$ and $\mathrm{A}-2, \mathrm{Fe}-$ rich region $\mathrm{B}$ and liquid region $\mathrm{C}$. According to the XRD and EDS analysis results of S1723 in Fig. 9 and Table 5, the region A-1 mainly contains $\mathrm{Ca}_{3}\left(\mathrm{PO}_{4}\right)_{2}, \mathrm{MgAl}_{2} \mathrm{O}_{4}, \mathrm{Mg}\left(\mathrm{Al}_{1.9} \mathrm{Fe}_{0.1}\right) \mathrm{O}_{4}$ and $\mathrm{Al}_{3.8} \mathrm{Mg}_{3.15} \mathrm{Fe}_{1}$ ${ }_{.05}\left(\mathrm{Si}_{1.75} \mathrm{Al}_{4.25} \mathrm{O}_{20}\right)$. Region A-2 mainly contains $\mathrm{Ca}_{3}\left(\mathrm{PO}_{4}\right)_{2}$ and $\mathrm{Ca}_{2} \mathrm{Al}_{2} \mathrm{SiO}_{7}$. Region $\mathrm{B}$ mainly contains $(\mathrm{Mg}, \mathrm{Fe})_{2} \mathrm{SiO}_{4}$, $\mathrm{MgAl}_{2} \mathrm{O}_{4}$ and $\mathrm{Mg}\left(\mathrm{Al}_{1.9} \mathrm{Fe}_{0.1}\right) \mathrm{O}_{4}$. The existence of $\mathrm{Al}_{3.8} \mathrm{M}$ $\mathrm{g}_{3.15} \mathrm{Fe}_{1.05}\left(\mathrm{Si}_{1.75} \mathrm{Al}_{4.25} \mathrm{O}_{20}\right)$ further confirms the results of Raman analysis and FTIR spectra analysis in section 3.2 that the $\left[\mathrm{AlO}_{4}\right]$ and $\left[\mathrm{SiO}_{4}\right]$ in slag will further form a more complex network structure at the higher end temperature of dephosphorization.

In addition, it can be found from Table 5 that the $\mathrm{Fe}$ content in Fe-rich region B in S1723 slag decreases compared with that in S1648 slag, which is mainly due to the formation of region A-1 with a part of Fe-rich region changed into region A-1. Moreover, the XRD analysis result of $\mathrm{S} 1723$ shows that there is a $\mathrm{MgAl}_{1.9} \mathrm{Fe}_{0.1} \mathrm{O}_{4}$ $\left(\mathrm{MgAl}\left[\mathrm{AlO}_{4}\right]_{0.9}\left[\mathrm{FeO}_{4}\right]_{0.1}\right)$ phase in the $\mathrm{S} 1723$ slag. It can be speculated that $\left[\mathrm{AlO}_{4}\right]$-tetrahedron replaces a part of $\left[\mathrm{FeO}_{4}\right]$ tetrahedron unit in $(\mathrm{Mn}, \mathrm{Mg}) \mathrm{Fe}_{2} \mathrm{O}_{4}$ of $\mathrm{Fe}$-rich region $\mathrm{B}$, and $\mathrm{MgAl}_{1.9} \mathrm{Fe}_{0.1} \mathrm{O}_{4}$ spinel is formed.

The main reasons for the absence of P-rich phase $\mathrm{nC}_{2} \mathrm{~S}-\mathrm{C}_{3} \mathrm{P}$ in $\mathrm{S} 1723$ are discussed as follows. Firstly, with increasing dephosphorization temperature, the equilibrium constant of the dephosphorization reaction decreases rapidly, while the decarburization reaction is promoted greatly. This will lead to the low contents of $\mathrm{FeO}$ and $\mathrm{P}_{2} \mathrm{O}_{5}$ in slag, which is not conducive to the formation of P-rich 

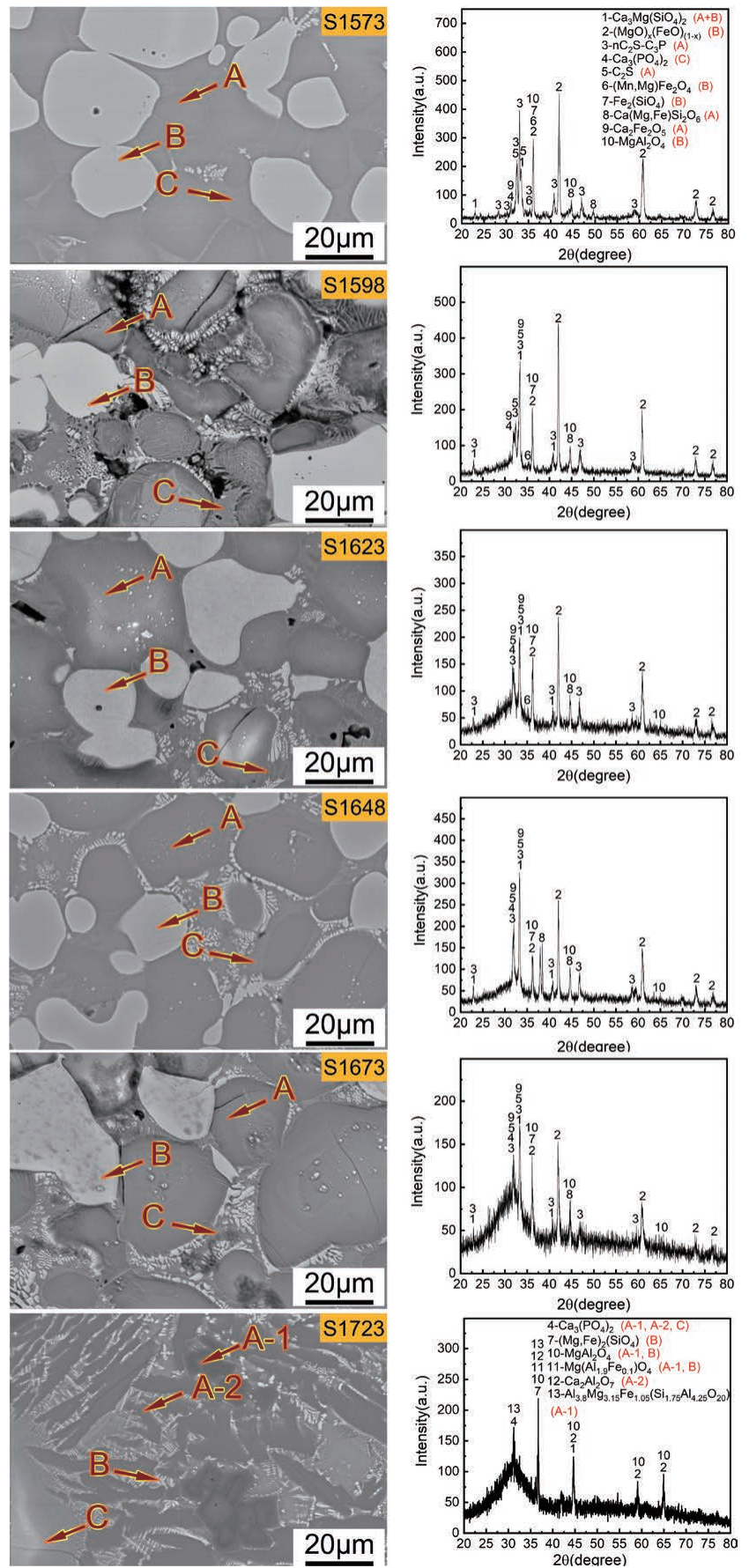

Fig. 9. SEM images and XRD analysis results of dephosphorization slag samples of S1573, S1598, S1623, S1648, S1673 and $\mathrm{S} 1723$

Table 5. Compositions of different regions in slag samples of S1648 and S1723 (mass\%).

\begin{tabular}{cccccccccc}
\hline Sample & Position & $\mathrm{Mg}$ & $\mathrm{Al}$ & $\mathrm{Si}$ & $\mathrm{P}$ & $\mathrm{Ca}$ & $\mathrm{Mn}$ & $\mathrm{Fe}$ & $\mathrm{O}$ \\
\hline \multirow{3}{*}{ S1648 } & $\mathrm{A}$ & 0.89 & 0.18 & 16.0 & 4.00 & 54.8 & 0.75 & 4.98 & 18.4 \\
& $\mathrm{~B}$ & 9.80 & 0.13 & 0.24 & 0.05 & 1.09 & 5.30 & 67.9 & 15.5 \\
& $\mathrm{C}$ & 1.09 & 10.4 & 11.4 & 0.10 & 35.0 & 2.36 & 21.3 & 18.5 \\
\hline \multirow{5}{*}{ S1723 } & A-1 & 10.3 & 34.2 & 2.31 & 0.53 & 4.42 & 4.21 & 15.2 & 28.8 \\
& $\mathrm{~A}-2$ & 1.00 & 17.4 & 13.6 & 0.65 & 39.4 & 1.65 & 4.14 & 22.2 \\
& $\mathrm{~B}$ & 4.29 & 2.62 & 7.59 & 0.04 & 15.8 & 8.45 & 40.9 & 20.3 \\
& $\mathrm{C}$ & 2.37 & 7.31 & 13.4 & 2.87 & 23.1 & 8.91 & 19.9 & 22.1
\end{tabular}

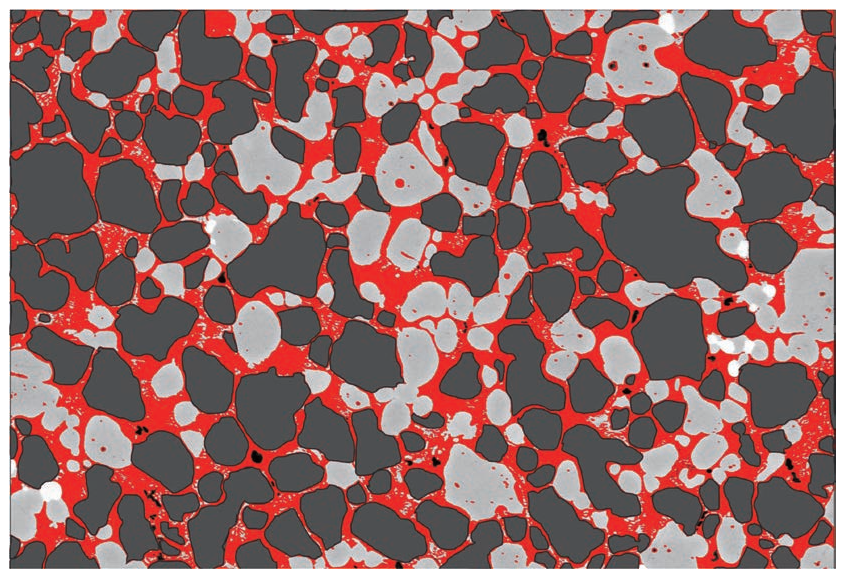

Fig. 10. SEM picture with the magnification of 200 times by manual confirmation.

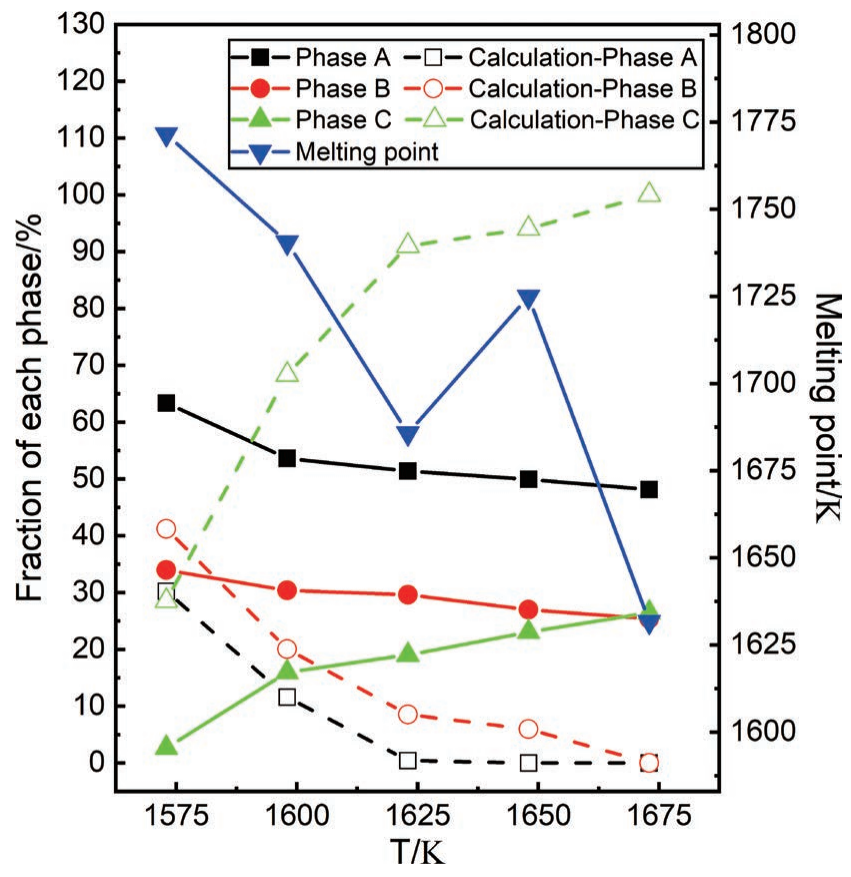

Fig. 11. Changes in the measured area fractions and the calculated mass fractions of different regions, as well as the melting point of the slags with the end temperature of dephosphorization.

phase $\mathrm{nC}_{2} \mathrm{~S}-\mathrm{C}_{3} \mathrm{P}$. Secondly, with increasing dephosphorization temperature, the increase of $\mathrm{Al}_{2} \mathrm{O}_{3}$ content in slag caused by the corrosion of alumina crucible will results in more formed $\left[\mathrm{AlO}_{4}\right]$-tetrahedral structural units. The $\left[\mathrm{AlO}_{4}\right]$-tetrahedral structural units can further combine with [ $\left.\mathrm{SiO}_{4}\right]$-tetrahedral structural units to form a more complex substance, so that the $\left[\mathrm{SiO}_{4}\right]$ in the free $\mathrm{C}_{2} \mathrm{~S}$ and $\mathrm{nC}_{2} \mathrm{~S}-\mathrm{C}_{3} \mathrm{P}$ will be captured. Besides, $\mathrm{Al}_{2} \mathrm{O}_{3}$ can also capture $\mathrm{C}_{2} \mathrm{~S}$ from the early precipitated solution to produce $\mathrm{Ca}_{2} \mathrm{Al}_{2} \mathrm{SiO}_{7}$ leading to increased $\mathrm{P}$ concentration in the P-rich phase. ${ }^{7,42)}$ Therefore, the value of $\mathrm{P}$ in this matrix phase near the $\mathrm{Ca}_{2} \mathrm{Al}_{2} \mathrm{SiO}_{7}$ phase is $2.87 \%$, as shown at the point $\mathrm{C}$ of S1723 in Table 4, which is significantly higher than that in the matrix phase without the $\mathrm{Ca}_{2} \mathrm{Al}_{2} \mathrm{SiO}_{7}$ phase with about $1.5 \%$ in our previous research. ${ }^{16)}$ As a result, $\mathrm{Ca}_{3}\left(\mathrm{PO}_{4}\right)_{2}$ can not further combine with free $\mathrm{C}_{2} \mathrm{~S}$ particles to form $\mathrm{nC}_{2} \mathrm{~S}-\mathrm{C}_{3} \mathrm{P}$ so that it will enter the matrix phase. 


\subsection{Proportion of P-rich Region, Fe-rich Region and Liquid Region of Dephosphorization Slag}

The proportions of $\mathrm{P}$-rich region $\mathrm{A}$, Fe-rich region $\mathrm{B}$ and matrix region $\mathrm{C}$ of dephosphorization slag at different temperatures will be discussed for dephosphorization slag at $1573 \mathrm{~K}-1673 \mathrm{~K}$ due to no P-rich region A formed at $1698 \mathrm{~K}$ and $1723 \mathrm{~K}$.

The changes in the area fractions of different regions with the end temperature of dephosphorization were analyzed with the SEM images of dephosphorization slag at $1573 \mathrm{~K}-1673 \mathrm{~K}$. The low magnification SEM images were selected for the analysis of the area fractions of different regions, and the Image-Pro Plus software was used for automatic statistics by the color difference among different regions. Because the color of the P-rich region $\mathrm{A}$ and liquid region $\mathrm{C}$ in slag were very similar, it was difficult to distinguish some areas accurately. To enhance the accuracy of statistics, each region area was confirmed by manual treatment in the present work. For example, Fig. 10 shows the manually confirmed SEM picture with the magnification of 200 times for the dephosphorization slag at $1648 \mathrm{~K}$, in which the red area is liquid region $\mathrm{C}$, the dark gray area is $\mathrm{P}$-rich region $\mathrm{A}$, and the white area is Fe-rich region $\mathrm{B}$.

The changes in the mass fractions of different regions with the end temperature of dephosphorization were also estimated using the Equilib module of Factsage 7.3. Figure 11 shows the changes in the measured area fractions and the calculated mass fractions of different regions, as well as the melting point of the slags with the end temperature of dephosphorization. The melting point is calculated by using Factsage 7.3 supposing that the slag reaches equilibrium. It demonstrates that with increasing temperature, the area fractions and mass fractions of the P-rich region $\mathrm{A}, \mathrm{Fe}-$ rich region $\mathrm{B}$ are decreased, while the area fractions and mass fractions of the liquid region $\mathrm{C}$ are increased. For region $\mathrm{C}$, the calculated mass fractions are much higher than those of the measured area fraction, while for regions A and B, the calculated mass fractions are much lower than those of the measured area fraction. This is because the actual dephosphorization time is quite short with only $15 \mathrm{~min}$ and the molten slag does not reach the equilibrium state. In addition, after experiments, the precipitation and growth of the crystalline phase in slag were desperately avoided with immediate quenching into water after taking out the crucible within $5 \mathrm{~s}$.

The reason for the changes in the area fractions and mass fractions of different regions is that the reaction between the carbon in hot metal and the $\mathrm{FeO}$ in slag is promoted with the increasing temperature. Besides, the oxidations of other elements are also promoted in this low-temperature range. Therefore, FeO consumption is increased, leading to the gradual reduction in the mass fraction of Fe-rich region $\mathrm{B}$ in slag. However, since the melting point of the slag decreases with increasing temperature as shown in Fig. 10, with increasing temperature, the proportion of liquid region $\mathrm{C}$ will be increased and $\mathrm{P}$-rich region $\mathrm{A}$ is correspondingly decreased. Therefore, when the temperature is in the range of $1573 \mathrm{~K}-1673 \mathrm{~K}$, with increasing temperature, the area fractions and mass fractions of the corresponding P-rich region A and Fe-rich region $\mathrm{B}$ decrease, while the liquid region $\mathrm{C}$ increases. However, the $\mathrm{P}_{2} \mathrm{O}_{5}$ content in $\mathrm{P}$-rich region $\mathrm{A}$ will be increased steadily due to the improvement of the kinetic condition of dephosphorization which is described in detail in our previous study. ${ }^{16)}$ Therefore, the dephosphorization ratio of hot metal will reach the optimum value of $73.4 \%$ at $1375^{\circ} \mathrm{C}$ as shown in Table 1 . However, when the temperature is further increased, P-rich region A disappears quickly, so that the dephosphorization ratio is decreased rapidly. For example, there is no P-rich region A in slag at $1723 \mathrm{~K}$ and the corresponding dephosphorization ratio is reduced to $23.5 \%$ as shown in Table 1 .

\section{Conclusions}

The structure and viscosity of the dephosphorization slag with low basicity at the low temperature range of 1573 $\mathrm{K}-1723 \mathrm{~K}$ are studied with high-temperature laboratorial experiments. The conclusions are summarized as follows:

(1) With increasing the temperature, the viscosities of different slags firstly decrease rapidly, then decrease slowly, and the activation energies of the corresponding slags increase.

(2) From the Raman spectra, in the $\left[\mathrm{SiO}_{4}\right]$-tetrahedron stretching region, the $\left[\mathrm{SiO}_{4}\right]$-tetrahedron structures unit with bridge oxygen numbers of $0,1,2$ and 3 appear near 850 $\mathrm{cm}^{-1}, 900 \mathrm{~cm}^{-1}, 950 \mathrm{~cm}^{-1}$ and $1080 \mathrm{~cm}^{-1}$, respectively. Non-Bridging Oxygen per Silicon (NBO/Si) values decrease with increasing the end temperature of dephosphorization, indicating the increase in the degree of polymerization (DOP) dephosphorization slag and the viscous flow activation energy of the dephosphorization slag. The results of Raman and FTIR spectroscopy are consistent.

(3) The dephosphorization slag in the temperature range of $1573 \mathrm{~K}-1673 \mathrm{~K}$ is mainly composed of P-rich region A containing $\mathrm{nC}_{2} \mathrm{~S}-\mathrm{C}_{3} \mathrm{P}$, Fe-rich region $\mathrm{B}$ mainly containing $(\mathrm{MgO})_{\mathrm{x}}(\mathrm{FeO})_{1-\mathrm{x}}$ and light gray liquid region $\mathrm{C}$ containing $\mathrm{Ca}_{3}\left(\mathrm{PO}_{4}\right)_{2}$. However, the slag S1723 is mainly composed of complex structure regions A-1 and A-2, Fe-rich region B and light gray liquid region $\mathrm{C}$. The main components of region A-1 and region A-2 are very close to $\mathrm{Al}_{3.8} \mathrm{Mg}_{3.15} \mathrm{Fe}_{1.05}\left(\mathrm{Si}_{1.75}\right.$ $\mathrm{Al}_{4.25} \mathrm{O}_{20}$ ) and $\mathrm{Ca}_{2} \mathrm{Al}_{2} \mathrm{SiO}_{7}$, respectively.

(4) With increasing temperature from $1573 \mathrm{~K}$ to 1673 $\mathrm{K}$, the proportion of liquid region $\mathrm{C}$ in slag increases, but the $\mathrm{P}$-rich region $\mathrm{A}$ and $\mathrm{Fe}$-rich region $\mathrm{B}$ correspondingly decrease.

\section{Acknowledgments}

This work is financially supported by the National Natural Science Foundation of China (Grant No. U1960202).

\section{REFERENCES}

1) Y. Ogawa, M. Yano, S. Kitamura and H. Hirata: Tetsu-toHagané, 87 (2001), 21 (in Japanese). https://doi.org/10.2355/ tetsutohagane1955.87.1_21

2) W. Fix, H. Heymann and R. Heinke: J. Am. Ceram. Soc., 52 (1969), 346. https://doi.org/10.1111/j.1151-2916.1969.tb11948.x

3) Y. M. Gao, S. B. Wang, C. Hong, X. J. Ma and F. Yang: Int. J. Miner. Metall. Mater., 21 (2014), 353. https://doi.org/10.1007/ s12613-014-0916-7

4) J. H. Park, D. J. Min and H. S. Song: Metall. Mater. Trans. B, 35 (2004), 269. https://doi.org/10.1007/s11663-004-0028-2

5) J. R. Kim, Y. S. Lee, D. J. Min, S. M. Jung and S. H. Yi: ISIJ Int., 44 (2004), 1291. https://doi.org/10.2355/isijinternational.44.1291 
6) Z. Wang, Y. Q. Sun, S. Sridhar, M. Zhang, M. Guo and Z. T. Zhang: Metall. Mater. Trans. B, 46 (2015), 537. https://doi.org/10.1007/ s11663-015-0303-4

7) Z. J. Wang, Y. Q. Sun, S. Sridhar, M. Zhang, M. Guo and Z. T. Zhang: Metall. Mater. Trans. B, 46 (2015), 2246. https://doi.org/10.1007/ s11663-015-0391-1

8) Z. J. Wang, Q. F. Shu, S. Sridhar, M. Zhang, M. Guo and Z. T. Zhang: Metall. Mater. Trans. B, 46 (2015), 758. https://doi.org/10.1007/ s11663-014-0270-1

9) Y. Lin, Y. Liu, K. Chou and Q. F. Shu: Ironmaking Steelmaking, 46 (2019), 987. https://doi.org/10.1080/03019233.2018.1470362

10) Q. F. Shu and Y. Liu: Ironmaking Steelmaking, 45 (2018), 363. https://doi.org/10.1080/03019233.2016.1274463

11) X. Han, J. Li, C. G. Zhou, C. B. Shi, D. L. Zheng and Z. M. Zhang: Ironmaking Steelmaking, 44 (2017), 262. https://doi.org/10.1080/030 19233.2016.1210371

12) W. K. Yang, J. Yang, Y. Q. Shi, Z. J. Yang, F. B. Gao, R. H. Zhang and G. F. Ye: Ironmaking Steelmaking, 48 (2021), 69. https://doi.org/ 10.1080/03019233.2020.1731256

13) B. Zhao, W. Wu, W. Wu, H. D. Meng, Q. Gao and Z. B. Guo: Steel Res. Int., 91 (2020), 2000021. https://doi.org/10.1002/srin.202000021

14) Y. J. Xia, J. Li, D. D. Fan and G. D. Hou: ISIJ Int., 59 (2019), 1519. https://doi.org/10.2355/isijinternational.ISIJINT-2019-052

15) C. M. Du, N. N. Lv, C. Su, W. M. Liu, J. X. Yang and H. C. Wang: J. Iron Steel Res. Int., 26 (2019), 1162. https://doi.org/10.1007/s42243018-00224-4

16) W. K. Yang, J. Yang, Y. Q. Shi, Z. J. Yang, F. B. Gao, R. H. Zhang and G. F. Ye: Steel Res. Int., 92 (2021), 2000438. https://doi.org/10.1002/ srin.202000438

17) W. K. Yang, J. Yang, Y. Q. Shi, Z. J. Yang, F. B. Gao, R. H. Zhang and H. Sun: Metals, 11 (2021), 417. https://doi.org/10.3390/ met11030417

18) A. Einstein: Ann. Phys., 324 (1906), 289

19) R. Roscoe: Br. J. Appl. Phys., 3 (1952), 267. https://doi.org/10.1088/ $0508-3443 / 3 / 8 / 306$

20) S. Wright, L. Zhang, S. Sun and S. Jahanshahi: Metall. Mater. Trans $B, 31$ (2000), 97. https://doi.org/10.1007/s11663-000-0134-8

21) X. Shen, M. Chen, N. Wang and D. Wang: ISIJ Int., 59 (2019), 9. https://doi.org/10.2355/isijinternational.ISIJINT-2018-479

22) S. L. Xie, W. L. Wang, Z. H. Pan, H. C. Li, D. Y. Huang and Y. Du: Steel Res. Int., 89 (2018), 1700516. https://doi.org/10.1002/ srin.201700516

23) L. Yao, S. Ren, X. Q. Wang, Q. C. Liu, L. Y. Dong, J. F. Yang and J. B. Liu: Steel Res. Int., 87 (2016), 241. https://doi.org/10.1002/ srin. 201500021

24) S. Sridhar, K. Mills, O. Afrange, H. Lörz and R. Carli: Ironmaking Steelmaking, 27 (2000), 238. https://doi.org/10.1179/030192300677534

25) K. Zheng, Z. T. Zhang, L. Liu and X. D. Wang: Metall. Mater. Trans. $B, 45$ (2014), 1389. https://doi.org/10.1007/s11663-014-0053-8

26) S. S. Jung and I. Sohn: Environ. Sci. Technol., 48 (2014), 1886. https://doi.org/10.1021/es404277w

27) P. Tarte: Spectrochim. Acta Part A, 23 (1967), 2127. https://doi.org/ 10.1016/0584-8539(67)80100-4

28) G. Leekes, N. Nowack and F. Schlegelmilch: Steel Res., 59 (1988), 406. https://doi.org/10.1002/srin.198801533

29) J. H. Park, D. J. Min and H. S. Song: ISIJ Int., 42 (2002), 38. https:// doi.org/10.2355/isijinternational.42.38

30) B. O. Mysen, F. J. Ryerson and D. Virgo: Am. Mineral., 66 (1981), 106.

31) J. Wong: J. Non-Cryst. Solids, 20 (1976), 83. https://doi.org/10.1016/ 0022-3093(76)90109-5

32) Z. J. Wang, S. J. Cai, M. Zhang, M. Guo and Z. T. Zhang: Metall. Mater. Trans. B, 48 (2017), 1139. https://doi.org/10.1007/s11663017-0924-x

33) M. Hass: J. Phys. Chem. Solids, 31 (1970), 415. https://doi.org/10.1016/ 0022-3697(70)90081-8

34) S. Agathopoulos, D. Tulyaganov, J. Ventura, S. Kannan, A. Saranti, M. Karakassides and J. Ferreira: J. Non-Cryst. Solids, 352 (2006), 322. https://doi.org/10.1016/j.jnoncrysol.2005.12.003

35) D. McKeown, F. Galeener and G. Brown, Jr.: J. Non-Cryst. Solids, 68 (1984), 361. https://doi.org/10.1016/0022-3093(84)90017-6

36) M. Mohri, Y. Sasaki and K. Ishii: ISIJ Int., 41 (2001), 410. https:// doi.org/10.2355/isijinternational.41.410

37) R. Zhang, Y. Min, Y. Wang and C. J. Liu: Iron Steel, 54 (2019), 30. https://doi.org/10.13228/j.boyuan.issn0449-749x.20180432

38) Y. Q. Wu, G. C. Jiang, J. L. You, H. Y. Hou and H. Chen: Acta Phys. Sin., 54 (2005), 961. https://doi.org/10.3321/j.issn:10003290.2005.02.079

39) T. Furukawa, S. A. Brawer and W. B. White: J. Mater. Sci., 13 (1978), 268. https://doi.org/10.1007/BF00647770

40) F. Domine and B. Piriou: J. Non-Cryst. Solids, 55 (1983), 125. https:// doi.org/10.1016/0022-3093(83)90012-1

41) H. Kim, H. Matsuura, F. Tsukihashi, W. Wang, D. J. Min and I. Sohn: Metall. Mater. Trans. B, 44 (2013), 5. https://doi.org/10.1007/ s11663-012-9759-7

42) L. Lin, Y. P. Bao, M. Wang and H. M. Zhou: Ironmaking Steelmaking, 41 (2014), 193. https://doi.org/10.1179/1743281213Y.0000000117 